Editorial

\title{
Sustainability Best Paper Awards for 2015
}

\author{
Marc A. Rosen \\ Faculty of Engineering and Applied Science, University of Ontario Institute of Technology, 2000 \\ Simcoe Street North, Oshawa, ON L1H 7K4, Canada; E-Mail: marc.rosen@uoit.ca
}

Received: 16 February 2015 / Accepted: 17 February 2015 / Published: 17 February 2015

Sustainability is instituting annual awards to recognize the most outstanding papers in the areas of environmental, cultural, economic, technical and social sustainability of human beings published in Sustainability.

We are pleased to announce the recipients of the first "Sustainability Best Paper Awards". Nominations were selected by the Editor-in-Chief and several Editorial Board members of Sustainability from all papers published in 2011. Separate awards are given to articles and reviews, reflecting the differences in these two categories of contributions.

We are pleased to announce that the following five papers were chosen to receive "Sustainability Best Paper Awards" for 2015. I congratulate all of the authors and thank them for their significant and important contributions to the field of sustainability. I also thank the members of the Selection Committee for their efforts.

\section{Article Award}

First Prize

\section{David J. Murphy, Charles A.S. Hall, Michael Dale and Cutler Cleveland}

Order from Chaos: A Preliminary Protocol for Determining the EROI of Fuels

Sustainability 2011, 3(10), 1888-1907; doi:10.3390/su3101888

Available online: http://www.mdpi.com/2071-1050/3/10/1888

Second Prize

\section{Anthony Halog and Yosef Manik}

Advancing Integrated Systems Modelling Framework for Life Cycle Sustainability Assessment Sustainability 2011, 3(2), 469-499; doi:10.3390/su3020469

Available online: http://www.mdpi.com/2071-1050/3/2/469 
Third Prize

Bertrand Hirel, Thierry Tétu, Peter J. Lea and Frédéric Dubois

Improving Nitrogen Use Efficiency in Crops for Sustainable Agriculture

Sustainability 2011, 3(1), 1452-1485; doi:10.3390/su3091452

Available online: http://www.mdpi.com/2071-1050/3/9/1452

\section{Review Award}

First Prize

Derek H. Lynch, Rod MacRae and Ralph C. Martin

The Carbon and Global Warming Potential Impacts of Organic Farming: Does It Have a Significant Role in an Energy Constrained World?

Sustainability 2011, 3(2), 322-362; doi:10.3390/su3020322

Available online: http://www.mdpi.com/2071-1050/3/2/322

Second Prize

Yvan Dutil, Daniel Rousse and Guillermo Quesada

Sustainable Buildings: An Ever Evolving Target

Sustainability 2011, 3(1), 443-464; doi:10.3390/su3020443

Available online: http://www.mdpi.com/2071-1050/3/2/443

\section{Award Selection Committee}

Editor-in-Chief

\section{Prof. Dr. Marc A. Rosen}

Faculty of Engineering and Applied Science, University of Ontario Institute of Technology, 2000 Simcoe Street North, Oshawa, Ontario, L1H 7K4, Canada

E-Mail: marc.rosen@uoit.ca

Section Editor-in-Chief

Prof. Dr. Helmut Haberl

Institute of Social Ecology, Alps Adria University, Faculty for Interdisciplinary Studies, Vienna, Austria

E-Mail: helmut.haberl@aau.at

Section Editor-in-Chief

\section{Prof. Dr. Vincenzo Torretta}

Department of Biotechnologies and Life Sciences, Insubria University, Via G.B. Vico 46, Varese I21100, Italy

E-Mail: vincenzo.torretta@uninsubria.it 
Section Editor-in-Chief

Dr. Derek J. McPhee

Director of Chemistry, Amyris, Inc., 5885 Hollis St, Suite 100, Emeryville, CA 94608, USA

E-Mail: mcphee@mdpi.com

(C) 2015 by the authors; licensee MDPI, Basel, Switzerland. This article is an open access article distributed under the terms and conditions of the Creative Commons Attribution license (http://creativecommons.org/licenses/by/4.0/). 